\title{
E-Catch-Fisheries Logbook Application Based on Regulation of the Minister of Marine and Fisheries of the Republic of Indonesia
}

\author{
Nur Afin Trionawan ${ }^{1 *}$, Amalia Diamantina ${ }^{2}$, Sekar Anggun Gading Pinilih ${ }^{3}$ \\ \{nurafintrionawan@gmail.com ${ }^{* 1}$, amalia_diamantina@undip.ac.id ${ }^{2}$ sekar_anggun@live.undip.ac.id ${ }^{3}$ \}
}

Fakultas Hukum, Universitas Diponegoro, Jl. Prof. H. Soedarto, S.H., Semarang, Indonesia $50275^{1}$

\begin{abstract}
Fisheries management using Log Book is deemed effective application called E-Log Book Fishing. With E Log Book, fishing activities are not bothered by filling in the data before the fish catch report, also the government will get easier to collect data on fish products because it is already online. The method used is this study is normative juridical with descriptive analysis as a specification. The data are sourced from the secondary data using primary, secondary, and tertiary legal materials. The method of collecting data consists of literature and interviews as supporting data. Research results show the application of E-Log Book Application of Fishing at the Ocean Fishery Port of Nizam Zachman North Jakarta requires a high level of involvement in the application of logbooks. The fishing vessels with 30 GT going through Indonesia is required to have VMS transmitters to transmit position data sent every 1 (one) hour continuously, provide socialization and train the use of E-Logbook for intensive fisheries with ease, and grant tolerance that is approved for the implementation of E-Logbook. However, the using of application still faces some problems such as the lack of socialization regarding elogbook applications, system error, weak monitoring of fishing operations at sea, and protection of Syahbandar (PPSNZJ).
\end{abstract}

Keywords: E-Log Book, fisheries, port and fishing.

\section{Introduction}

\subsection{Background}

The Republic of Indonesia is a country that has a diverse natural resources from agriculture, plantations, and fisheries. Indonesia is an archipelagic country which consists of many islands where the sea, air and land are united which is geographically apparent that Indonesia has a wider water compared to the mainland. [1]

As an archipelagic country, Indonesia has potential for fish resources. The potential of this fishery can be relied on to meet domestic consumption and foreign exchange earners. For this reason, it is necessary to manage fisheries appropriately so that fish resources can be utilized sustainably. The huge potential of fisheries can provide maximum benefits if managed properly and responsibly. It has also been mandated in Law of the Republic of Indonesia Number 45 of 2009 article 6 paragraph 1 which emphasizes that fisheries management is 
aimed at achieving optimal and sustainable benefits, and ensuring the preservation of fish resources [2], [3]

Illegal fishing or so-called illegal fishing (Illegal Fishing) is very detrimental to the country and traditional fishermen. Illegal fishing done by both illegal Indonesian fishermen and unregistered foreign fishermen has caused no fishing activities to be detected, making it difficult to control the availability of fish resources. In addition, other people who become consumers are also disadvantaged because they cannot enjoy sea products in their own country. At a macro level, the stolen Indonesian fish are then processed with qualified equipment, thereby increasing the selling price abroad. [4]

Fish resources that live in territorial waters in Indonesia are considered to have the highest level of biodiversity (bio-diversity). These resources cover at least $37 \%$ of the world's fish species. There are several types of fish with high economic value including tuna, skipjack, shrimp, tuna, mackerel, snapper, squid, reef fish (grouper, baronang, barong shrimp/lobster), ornamental fish and drought including grass the sea. However, there are various gaps that still color fisheries development in Indonesia both nationally and locally administratively managing. [5] Various infrastructures built by the government, such as the construction of fishing ports and fish landing places which are scattered in various regions have not yet produced satisfactory results as expected., Various regulatory models and policies have not been able to fix the underlying problems that exist. [5]

The problem of illegal fishing (fishing theft) and weak law enforcement have in fact eliminated the potential for Indonesian fishery exports of 4 billion US dollars. In addition to harming the country, illegal fishing also harms traditional fishermen because they use trawling fishing gear that causes damage to the marine environment.. Illegal fishing can also weaken the management of fisheries resources in Indonesian waters and cause fisheries resources in

several Fisheries Management Areas (WPP) of Indonesia to experience overfishing. [6] Overfishing is a term or status given to an area of water whose fish resources have experienced overfishing. Over-fishing is meant if the rate of fishing carried out has exceeded the ability of these fish resources to recover. [7]

\subsection{Formulation of the problem}

1. How is the application of E-Fishing Logbook at the Port of Ocean Fisheries Nizam Zachman North Jakarta?

2. What are the obstacles encountered in implementing the Fishing E-Log Book application and how to overcome them?

\subsection{Research Purposes}

The expected objectives of this study are as follows:

1. To find out the application of the E-Log Book of Fishing in the Port of Ocean Fisheries Nizam Zachman North Jakarta.

2. To find out the obstacles faced in the application of E-Log Book Catching Fish and How to Overcome It. 


\section{Method}

This research is qualitative because this research focuses more or relies on the depth of the data not the amount of data obtained. Viewed from a scientific perspective, this research is legal research.

A juridical-normative approach is a method of approach that emphasizes understanding in obtaining answers by basing on legal principles and principles obtained from regulations and trying to synchronize the legal provisions that apply to legal protection against norms or regulations other law with relation to the application of the legal regulations in practice in the field. [8]

The specifications of this study use descriptive analytical research specifications. Descriptive analytical research that describes the applicable laws and regulations associated with legal theories and the practice of implementing positive law relating to the problem. [9]

Data analysis is very important in a study because its roles are to provide answers to the problems. Before data analysis is performed, data collection is first held. The method used in analyzing and processing the collected data is qualitative analysis, namely by explaining and presenting data in a structured form then drawn conclusions descriptively. [9]

\section{Results}

\subsection{History of Manually Fishing Log Book}

The Fishing Log Book is a daily report written by the boat captain regarding fishing activities. Log Book Fishing is needed in the collection of data on fish catches, namely recording the type of fish caught, the amount of fish caught, the position/location of fish catches and the time of catching fish. [10]

Realizing the importance of using log books, the Directorate of the Ministry of Maritime Affairs and Fisheries (KKP) tried to improve the recording system that had been implemented by adding some features more details. Fisheries data collection strategy should be confirmed as a program that is routine in nature and in the long term (long-term observation) one of which is the use of Log Book. The important objectives of the Log Book are as follows: [11]

1. Log Book as Landing Declaration of the ship's captain, or a statement regarding the fish brought to the fishing port.

2. Fishery Log Book supports data collection on fisheries (fishing area, fish species, and volume).

3. Fishery Log Book records data on fishing permit (fishing gear) of vessel registration data (LxBxD; Power), the port of the ship's base.

4. Supports the evaluation and analysis of SDI management (fishing capacity, efficient fishing, catch season in relation to open and close sessions, and conservation).

\subsection{Application of E Log Book of Fishing at the Ocean Port of Fisheries Nizam Zachman Jakarta}

Electronic Logbook is a tracking system (tracking system) that only provides information about ships carrying transmitter equipment. Unlicensed vessels and other vessels not equipped 
with suitable transmitters cannot be monitored by e-logbooks. Satellite-based e-logbook technology includes three important components which are subsystems, namely: [10]

1. A transmitter or transceiver mounted on a fishing vessel to indicate the position of the ship.

2. Transmission medium/communication system, which is a satellite system worked as a vehicle to transmit ship position information from fishing vessels to the Fisheries Monitoring Center.

3. Fisheries Monitoring Center (FMC) to receive, store, display and distribute data. Data in FMC can be further analyzed for specific purposes. The mechanism of action of an e-logbook is generally preceded by a transmitter that sends ship position data through a satellite system that circulates in its orbit above the earth. The satellite will receive a message from the ship and send it to the satellite data processing center, and then the data of the position of the processed ship is delivered to FMC continuously.

Fishing e-logbook application is a technology created to replace paper-based logbooks (manual logbooks) due to less efficiency. In addition, it has various kinds of obstacles such as a lot of data that must be written, illegible writing, easily damaged paper and determining inaccurate fishing locations. [12]

\subsubsection{Following is the E-Logbook Implementation Strategy. [12]}

1. Implementation at the fishing port with a high level of compliance with the implementation of the logbook is based on several criteria, namely:

a. Timeliness of delivery of logbook data on catches with fishing gear

b. Suitability of the catch fish with the fishing area

c. Suitability of trip length with number of settings

d. The fishing position is conveyed at the logbook officer entry at the port

e. Fostering the fishing port for fisheries businesses related to the implementation of the fishing logbook

2. Application on ships that have used VMS transmitters. Fishing vessels above $30 \mathrm{GT}$ that operate in Indonesian waters or on the high seas must install a VMS transmitter online by sending vessel position data every 1 (one) hour continuously.

3. Intensive socialization and training on the use of E-Logbook to fishermen with simple/easy to understand language.

4. Imposing strict sanctions for violations in the implementation of E-Logbook. ELogbook fishing is a document that is required to obtain a Certificate of Fishing (SHTI), which is an important document for exporting tuna, as well as the issuance of proof of fishing vessel arrival reports by the fishing port. The sanctions for vessels that do not report E-Logbooks in the form of non-issuance of Sailing Permit (SPB), freezing of Fishing License (SIPI)., It will work again after the revocation of SIPI, that and the application of electronic log books can work again., it is necessary to impose strict and consistent sanctions for violations of their implementation. In addition to sanctions, it is also necessary to reward ships with compliance with high electronic logbook compliance. The award can be in the form of ease in the licensing process, ease in obtaining fuel subsidies, and ease in obtaining assistance from the government.

5. Cooperating with third parties. To ease the burden on fishermen in the cost of hardware procurement and the cost of e-log book pulses, the Ministry of Maritime Affairs and Fisheries can collaborate with third parties or the private sector in the 
field of communication for the supply of hardware, SIM card issuance and special pulses for e-log books.

\subsection{Obstacles to PPS Nizam Zachman in Efforts to Implement E-Logbook Application for Fishing}

The Fishery Port is an extension of the Directorate General of Capture Fisheries, the Ministry of Maritime Affairs and Fisheries in the area. To support the vision of the Directorate General of Capture Fisheries of the Ministry of Maritime Affairs and Fisheries, PPS Nizam Zachman Jakarta based on Port Head Decree Number KPTS.08/PPSNZJ.A/HM.160/I/2015 establishes the vision of PPS Nizam Zachman Jakarta, [13] namely "Realizing an Independent, Advanced, Strong and Strong and National Interest Based Indonesian Maritime Sector." In the future, it is intended that Indonesia can rely on its own capabilities and strengths in managing marine and fisheries resources so that they can compete equally with other fishermen from other nations. Forward is intended to manage marine and fishery resources with the strength of competent human resources and innovative and value-added science and technology, to achieve high and equitable public welfare.[14]

The fishing port is a working environment so in its management the Jakarta Nizam Zachman Ocean Fishery Port (PPSNZJ) is managed by the Technical Implementation Unit (UPT), the Indonesian Fisheries General Corporation (Perum Perindo) and other relevant agencies. These agencies cooperate with each other in carrying out port operational activities, functioning, developing, maintaining or maintaining, as well as maintaining the cleanliness of all existing facilities at the Fishery Port, both basic facilities, supporting facilities and their supporters.

Jakarta Nizam Zachman Ocean Fisheries Port (PPSNZJ) carries out government functions at the port, led by the Head of the Port, who has a structural position echelon II.B. The Fishing E-Logbook application implemented at PPS Nizam Zachman encountered several obstacles in its application.

\subsubsection{Lack of Socialization of Fishing E-Logbook Application}

The application of the E-Logbook application which was started to launch from November 2018 requires a gradual socialization, while the socialization conducted by the Ministry of Maritime Affairs and Fisheries was only held once in November 2018 when the ELogbook Application was first implemented at the Nizam Zachman PPS. In reality on the ground, there are still many fishermen who are confused and wrong in running the E-logbook application. These errors include filling in the catch data as it is, not routinely in reporting daily catches, to charging carried out on land.

\subsubsection{There Are Still System Errors In The Fishing E-Logbook Application}

The Fishing E-Logbook application developed by the Center for Research and Engineering of Marine and Fisheries Technology (P3TKP) - KKP to facilitate fishermen in filling the Log Book and supporting government data in fisheries management is not yet perfect. In the operation of the Fishing E-Logbook application, there are still some system errors found. One user of the Fishing E-Logbook Application is having trouble for not being able to run; and instead it got freezed. 


\subsubsection{Weak Monitoring of Fishing Operations in Waters}

Supervision of fishing operations needs to be increased in terms of number, so that it will be able to meet the interests of the management of fish resources in PPS Nizam Zachman. Facilities and infrastructure of collecting fisheries statistics and fishing Log Book must be able to meet the data needs of management of fish resources. Training and technical guidance must be routinely carried out and increase the number of data enumerators and fishing log book officers.

The Ministry of Maritime Affairs and Fisheries has begun implementing an electronic Log Book system in November 2018 to record fish catches. This application was initially applied at the Nizam Zachamn PPS and several areas that have fishing ports to facilitate the collection of fishery products and support fisheries supervision in Indonesia.

Fisheries supervisors must make improvements in the collection of fish catches by educating fishermen on how to use and activate the E-Logbook.

\subsection{Manual Log book Obstacles}

The reality in the field, the use of E-Log book is still experiencing problems, so it must use a manual Log Book that has many obstacles. These constraints include the amount of data that must be filled in and the writing is not easy to read. Other cases, paper that is easily wet and torn and the problem of secrecy of the location of the arrest caused the log book was not permitted correctly. In addition, the application of log books still does not provide direct benefits to fishermen, so they do not feel they have an obligation to fill in the results of their capture on the log book forms that have been determined.

The low level of implementation of the log book is apparently due to the absence of intensive socialization and strict sanctions in implementing the ministerial regulation. To overcome the obstacles in manually filling in the fishing log book, an electronic-based fishing book has been developed or known as an electronic log book. With the use of electronic log books, fisheries data and information will be obtained more accurately related to fishing activities, so that they can support optimal and sustainable fish resource management policies and ensure the sustainability of fish resources.

\section{Discussion}

To overcome the obstacles in manually filling in the fishing log book, an electronicbased fishing book has been developed, and launched to the public. . With the use of electronic log books, fisheries data and information will be obtained more accurately related to fishing activities, so that they can support optimal and sustainable fish resource management policies and ensure the sustainability of fish resources. The purpose of this research is to study the application of e-log books in Indonesia which outlines the technical aspects of e-log book technology, to compare the application of e-log books with the ones in other countries, and to see the implementation strategies for sustainable management of fish resources. For the initial stage of implementing an e-log book, it can be done at a fishing port with a high level of compliance with the implementation of a fishing log book. The high level of compliance with the implementation of the log book is based on several criteria. These criteria include: 1) the timeliness of fishing log data entry; 2) the suitability of the catch fish with the fishing gear; 3 ) the suitability of the catch fish with the fishing area; 4) the compatibility of trip length with 
number of settings; 5) the arrest position; 6) the completeness of the fishing log log data submitted by the log book officer at the port, and; 7) fostering fishing port for fisheries business actors related to the implementation of fishing log book (PPN Pemangkat, 2013). Based on these criteria, there are ports with high levels of compliance with the implementation of log books in 2012, namely: PPS Nizam Zachman, PPN Ternate, PPN Pemangkat, and PPP Kwandang (PPS Nizam Zachman, 2013).

Application of e-logbook will be applied first on fishing vessels that already use VMS transmitters. The initial stage of implementing an e-log book can also be carried out on ships that have used a VMS (Vessel Monitoring System) transmitter. The operationalization and operation of VMS for fishing vessels is currently regulated by the Minister of Maritime Affairs and Fisheries Regulation Number 10/PERMEN-KP/2013 concerning Fisheries Vessel Monitoring System. [15] This regulation requires fishing vessels over 30 GT operating in Indonesian waters or on the high seas must install an online VMS transmitter with continuous ship position data every 1 (one) hour.

Intensive socialization and training in using electronic log books to fishermen. When the electronic log book is implemented, it is necessary to conduct intensive socialization and training directly to the skipper with simple/easy to understand language. This socialization and training is also given to port officers, so that they can provide training directly to fishermen/skippers. This socialization can also be done by involving local community leaders.

Imposing strict sanctions for violations in the implementation of electronic log books. The fishing log book is a document that is required to obtain a Certificate of Catching Fish (SHTI) which is an important document for exporting tuna, as well as for the issuance of a proof of fishing vessel arrival report by the fishery syahbandar,[16] a fishing log book is a document required for the issuance of a Sailing Approval Letter (SPB). In the regulation, sanctions are regulated for vessels that do not report log books. The sanctions are in the form of non-issuance of Sailing Permit (SPB), freezing of Fishing License (SIPI), until the revocation of SIPI. So that the application of electronic log books can work well, it is necessary to impose strict and consistent sanctions for violations of their implementation. In addition to sanctions, it is also necessary to reward ships with compliance with high electronic $\log$ book implementation. The award can be in the form of ease in the licensing process, ease in obtaining fuel subsidies, and ease in obtaining assistance from the government.

Cooperating with third parties is highly needed. To ease the burden on fishermen in the cost of hardware procurement and the cost of e-log book pulses, the Ministry of Maritime Affairs and Fisheries can collaborate with third parties or the private sector in the field of communication for the supply of hardware, SIM card issuance and special pulses for e-log books.

\section{Closing}

\subsection{Conclusion}

The use of e-log book technology is the right choice nowadays to accelerate and improve the accuracy of fishing data. The accuracy of fishing data is very much needed to support the management of fish resources. For this reason, one way to obtain fishing data is by using a fishing log book. The data obtained can be used to limit fishing areas in case of overfishing, to 
gather information about fish catches, to prevent of illegal fishing are the basis for government decisions.

1. The application of e-log books in Indonesia can be done by looking at the comparison of the implementation of e-log books fishing month to month to see the improvement. Based on the research the author did at PPS Nizam Zachman, the application of the E-LogBook Fishing Application showed an increase in the activation of the ELogbook and an increase in reporting using the E-Logbook application. The data shows the level of compliance and application of the E-Logbook application is very good. Technologically, the e-log book developed is ready to be used in the field of fish resource management in terms of hardware, software, data communication (satellite and GSM/GPRS), and system integrators.

2. E-Fishing logbook application that is implemented at PPS Nizam Zachman has several problem, such as:

a. The Lack of socialization regarding fishing e-logbook applications

b. The system of apps still found errors while running it

c. Weak supervising and;

3. Lack of quality HR in running the E-Logbook Fishing application.

4. From the regulatory base, a legal regulation needs to be made as a basis for the implementation of e-log books in Indonesia.

\subsection{Suggestion}

Based on the description that has been explained in the discussion in the previous chapter, it can be concluded that the use of the e-log book requires the application strategy. The strategies suggested by NPS Nacham Zachman PPS are as follows:

1. Intensive socialization and training to use electronic log books to fishermen is highly needed.

2. In response to the problems on the apps, there must be an improvement to perform better

3. To apply in imposing strict, fair and equitable sanctions for violations in the implementation of electronic log books; and

4. To involve third parties such as private companies in the field of communication technology. 


\section{References}

[1] W. Soedjono, Pengangkutan Laut dalam Hubungannya dengan Wawasan Nusantara. Jakarta: PT Bina Aksara, 1983.

[2] Direktorat Kelautan dan Perikanan Kementerian PPN/Bappenas, Kajian Strategi Pengelolaan Perikanan Berkelanjutan. Jakarta: Kementerian PPN/Bappenas, 2014.

[3] Law Number 45 of 2009 concerning Amendment to Law Number 31 of 2004 . .

[4] D. Tribawono, Hukum Perikanan Indonesia. Jakarta: Citra Aditya Bakri, 2011.

[5] S. V. Muhamad, "Illegal Fishing Di Perairan Indonesia: Permasalahan Dan Upaya Penanganannya Secara Bilateral Di Kawasan," J. Polit. Din. Masal. Polit. Dalam Negeri dan Hub. Int., vol. 3, no. 2, 2016.

[6] D. Sunyowati, Port State Measures dalam Upaya Pencegahan terhadap IUU Fishing di Indonesia, Peran Hukum dalam Pembangunan di Indonesia. Bandung: Remaja Rosdarkarya, 2013.

[7] S. A. Murawski, "Definitions of overfishing from an ecosystem perspective," ICES J. Mar. Sci., vol. 57, no. 3, pp. 649-658, 2000.

[8] B. Ashofa, Metode Penelitian Hukum. Jakarta: Rineka Cipta, 2001.

[9] R. H. Soemitro, Metodologi Penelitian Hukum dan Jurimetri. Jakarta: Ghalia Indonesia, 1998.

[10] A. Rifai, "Uji Kinerja Alat Elektronik Logbook (E-Logbook) Perikanan," Institut Pertanian Bogor, 2012.

[11] WWF Indonesia, "Log Book Perikanan: Menyensus Laut Kita.” [Online]. Available: https://www.wwf.or.id/?23481/log-book-. [Accessed: 15-Jul-2019].

[12] N. N. Nugroho, H., Sufyan, A., \& Wiadnyana, "Aplikasi teknologi elektronik log book penangkapan ikan untuk mendukung pengelolaan perikanan," J. Kelaut. Nas., vol. 10, no. 3, pp. 113-124, 2017.

[13] PPS Nizam Zachman Jakarta Port Head Decree Number KPTS.08/PPSNZJ.A/HM.160/I/2015 concerning on vision of PPS Nizam Zachman Jakarta. .

[14] PPS Nizam Zachman Jakarta, "Visi, Misi, Tujuan Dan Sasaran Strategis." [Online]. Available: https://kkp.go.id/djpt/ppsnzj/page/1105-visi-misi-tujuan-dan-sasaranstrategis. [Accessed: 16-Jul-2019].

[15] "Regulation of the Minister of Maritime Affairs and Fisheries of the Republic of Indonesia Number 10/PERMEN-KP/2013 concerning Fisheries Vessel Monitoring System."

[16] Regulation of the Minister of Maritime Affairs and Fisheries of the Republic of Indonesia Number 48/PERMEN-KP/2014 Regarding Fishing Book Log. . 